\title{
MULTI-DIMENSIONAL BORDERS IN NARRATION
}

\author{
Tiiu Jaago \\ Associate Professor of Estonian Folklore \\ Institute of Cultural Research, University of Tartu, Estonia \\ e-mail: tiiu.jaago@ut.ee
}

\begin{abstract}
The article analyses the story of two Estonian soldiers (so-called Finnish Boys, a volunteer Estonian unit in the Finnish army), who escaped the Finnish army during the Continuation War. The reason for their desertion was the fact that the Estonians who were serving in the Finnish army were to be sent back to Estonia, where they would have had to serve in the Nazi German Army. They crossed the Finnish-Swedish border at Tornio/Haaparanta in the autumn of 1944. The story was recorded by the narrators themselves in Sweden in 1975. In the article, this story of the escape and state border crossing is dealt with from the aspect of experience and narration. Questions arise concerning how the territorial border is marked in the narrative, where the symbolic borders are revealed, and how the narrators interpret the moral aspects related to the border and its crossing.
\end{abstract}

Keywords: border, Continuation War, experience, Finnish Boys, life story, narrative

This article focuses on a narrative about borders. The observed story was narrated by two men who recalled their war experience, including their escape from Finland to Sweden in the turmoil of World War II. The article asks how the narrators visualise the state border, how they position themselves in relation to the events before and after the state border crossing, and how the change in their roles influences the style of the narrative, as well as what kind of more general (political, autobiographical, etc.) contexts they keep in mind while interpreting their escape. Although the narrated escape story focuses on the details of the state border and crossing thereof, it covers territorial, political, cultural, narrative, and autobiographical aspects. The analysis is based on the folkloristic research of real life narratives (see Apo 1995; Allison 1997; Palmenfelt 2006): which events of their lives people talk about, in which circumstances they do it, and what factors affect the narrative. Therefore, the focus is laid, on the one hand, on the real-life experience (from the point of view of both the experience 
and the social-cultural environment of the narrators or their audience), and, on the other hand, on narrating as a cultural practice. The first half of the article includes biographical, historical, and theoretical references that provide a background to the text analysis presented in the second half of the article.

\section{EVENTS AND MEMORY: HISTORICAL AND BIOGRAPHICAL BACKGROUND}

The analysed story is a conversation between two men, in which they recall events that took place in Northern Finland in the late summer of 1944. At that time, they were fighting in the Continuation War as Estonian volunteers in the Finnish Army Infantry Regiment 200. There were slightly more than 3,300 such volunteers. Most of them, like these men, escaped from Estonia to Finland in 1943, when recruitment to the German Army started in Estonia. In August 1944 the volunteers were sent back to Estonia, where they still had to join the German Army, from which they had fled to Finland one year before (see Noormets 2011: 41-44). The protagonists of the observed story decided not to return to Estonia in August 1944, but to escape to Sweden. In Sweden their paths parted, until they met at the turn of 1974 in Stockholm to remember the days spent as volunteers in Finland. One of the men recorded this conversation for the purposes of his family archive. The recorder's wife handed over this tape to the Estonian Life Histories Association in 2008. It appeared that this recording no longer had a meaning for the family archive, as their descendants living in Sweden did not understand Estonian. Furthermore, this recorded story had exceeded the family's sphere of interest after the Cold War and the restoration of independence in Estonia. This issue had become one of the parts of the public discussion in the new historical frame. This article is based on the above-mentioned recording. At this time the digital copy of this recording is retained in Tartu, in the Estonian Life Histories collection of the Estonian Literary Museum (EKLA 350: 2525). The length of the recording is 1 hour and 15 minutes. During this time the men recall the explosion that took place in the Jalkala training camp in Finland, then they reminisce how they fled to Sweden, and finally they evaluate their choices and the fate of their war companions in a broader historical-political context. In addition, the background of this recording is reflected in an interview with the wife of the recorder of the memories in Stockholm in 2008 (MK: Stockholm 2008, E. T.).

Regarding the lives of these men, it is known that the recorder of this story was born in Tallinn in 1925. In the summer of 1943, he had just completed studies at Gustav Adolf Gymnasium in Tallinn. In February 1943, a call for 
mobilisation had been announced in the recently-occupied Estonia for men born between 1919-1924. Many conscripts found the opportunity to flee to Finland to escape recruitment by the German occupation troops (Leemets 1997; cf. Varblane 2011: 165-167; Jaago 2011: 326-329). Although he was not yet included in the draft (the respective order for those born in 1925 was issued in October 1943), he went to Finland in place of his friend. His friend had managed to procure a place in a refugee boat for himself, but at the last minute nonetheless decided to stay in Estonia, because he had a wife and a child in Estonia. The mother and father of the protagonist of this story, on the other hand, had recently died and he had been left alone in Tallinn. In 2008 his wife talked about it as a very quick decision: one summer day his friend had made this proposal and already the same evening he was on board as a refugee going to Finland. In the early autumn of 1943 he was enrolled in the Finnish army (see Leemets 1997). After the war he went to Germany to study (according to his wife he could not study in Sweden because the Swedish government did not accept the Estonian gymnasium certificate), and then worked as an architect in Sweden. He died in Stockholm in 1990. His partner on the escape journey in 1944, as well as in the conversation recalling that event, was much older than him, born in Russia in 1912. Before the war he had worked in western Estonia as a car mechanic. Soon after escaping from the Finnish army to Sweden he also found a job, as he had good qualifications (see also Leemets 1997; MK: Stockholm 2008, E. T.). It appears from the narrator's wife's explanations (and it can also be deduced from the men's reminiscences) that it was this older man whose initiative it was to escape to Sweden: he could not return to Estonia because he had an unresolved conflict with the German occupation authorities. During the events of 1944, one of the men was 19, the other 32 years old. When they met again in Sweden in the 1970s, they were 49 and 62 years old, respectively.

The biographies of the men show that crossing of the Finnish-Swedish border, which is the focus of this article, was not, by a long stretch, the only border crossing in their lives. Although all the crossings were interrelated, it was namely this particular one that had the greatest impact on the men's lives. So, the storytellers reminisced about the event that crucially changed their lives - their escape to Sweden. They also shared a military background: this is especially emphasised in their discussion about the aftereffects of the war. However, after that crucial event they did not meet again, as is revealed in their life stories. One might ask what made them look for one another's company after thirty years. Two factors should be considered here. On the one hand, the in-between period primarily involved adaptation to life in a new country, but by this point they had achieved certain stability. The activation of autobiographical memory and the need to reminisce about past events is related 
to a psychological process that helps in adapting to a new stage in life (Bluck \& Alea 2008: 56). The other aspect, however, is the general context of collective memory. Just prior to this (1973), the first overview of Estonian young men who had served in the Finnish Army had been published (Uustalu \& Moora 1973). In the analysed interview text, the phrase "but now, in hindsight, as you read this book" is likely to refer to that book. It should also be mentioned that the international celebrations of émigré Estonians (the so-called Esto Festivals) started in the 1970s, i.e., at the same time that the story discussed in this article was recorded. Perhaps the emergence of this topic in the collective Estonian consciousness inspired these men to observe their own individual experiences within the overall picture. A 2006 study by Tiina Kirss, who has researched Estonian refugee communities, revealed that "Estonians who had escaped to the West were aware of themselves collectively as companions-in-fate" (2006: 626) and one of the manifestations of such awareness was narrating stories about the escape. Referring to the context of the memory culture, Kirss asks what role was played by the narration of escape stories in this awareness of belonging, whether it was informal and among close associates only, or during the celebration of anniversaries and other important days, when people not only reminisced about how their escape took place, but also about why and from what they escaped (Kirss 2006: 626).

Understandably, also the memory analysed herein is a part of the process described by Kirss, but a specific feature of this particular case is that the men were not private civilians escaping, since at the moment of the escape they were deserters. Obviously, this was not a fact that they would have liked to emphasise immediately after the war, while adapting to life in a new country. This was probably also the reason why the passage of time was needed for recalling these end-of-war events.

\section{BORDERS, EXPERIENCE, AND NARRATIVE: THEORETICAL BACKGROUND}

The more general context for the analysis of this narrative is provided by interdisciplinary border studies, in which the border is dealt with as a multi-level and processual phenomenon (Paasi 1996: 15-16; Newman 2003: 13-14; Custred 2011). In this narrative, the border is first signified as the state border between Finland and Sweden. In the context of World War II, however, the border also had a symbolic meaning - on the one side there were the warring countries (including Finland, Nazi Germany, and the Soviet Union), and on the other side there was Sweden, which maintained neutrality during the war. The third 
level is the border associated with Estonia: on the one hand, it was the narrators' home, and on the other hand, an area controlled by occupation authorities.

From the viewpoint of real life narrative, one of the most important categories of the analysis of the observed story is experience (see Pickering 2008). On the one hand, experience is based on what a person has lived through. However, on the other hand, when talking about experience, one also has to consider how the social-cultural and historical-political backdrop affects the choices made in real life as well as how narrators interpret their choices. Therefore, we may ask about the border experience of the narrators, but we are also interested in how they present and interpret their experience. As experience is in the narrative form here, the mutual relationship of the situated and the mediated experience has to be taken into account in the analysis. The research of experience is based on the principle that the story provides access to a past event, but the narrative and the narrated event can be interpreted in a more general, communicative context (see Pickering 2008: 28). Real-life stories are always also cultural texts, in which both the conceptualising of what happened, other similar or related texts, and the imaginary auditorium have their role (Lawler 2008: 48). In this sense, experience is a continually-developing phenomenon: relying on a specific real-life event, experience at the same time also embraces the meanings and associations of the time the narration covers.

Through the narrative, as one possibility for expressing experience, this analysed story is also associated with border poetics research (see Schimanski $\&$ Wolf 2010). Border poetics research studies also reveal the processual and multi-level nature of the border: for example, the crossing of the state border as a certain obstruction (barrier) brings up the topic of symbolic borders, which are not exclusively related only to the decisions and actions of the one who crosses as an individual person. Schimanski (2006: 53) shows that border-crossing narratives can also be analysed "for their textual, topographic, symbolic, temporal and epistemological dimensions". On the textual level are the analysed topics, episodes, imagery, etc. The topographical level is associated with a certain spatial dimension, and the temporal level refers to both the biographical and the historical time scale. Symbolic borders are the subjective or perceived borders. The epistemological level distinguishes the known from the unknown. For example, as Schimanski (2006: 56) explains, "Epistemological borders are often placed between home territory and foreign places".

In the text analysis all these aspects (relations of experience and expression) are interconnected: the description of crossing the state border is related to the experience of the specific activity as well as describing the features of the real border. The latter includes both descriptions of the landscape and the protagonists' feelings and thoughts at that moment. It can also be noted in the text 
how the way of describing is completely different after the border crossing, be it caused by the change of the role of the protagonists in the new circumstances or the description of "another" landscape and culture.

\section{TEXT ANALYSIS}

The audio recording of the escape story was transcribed for analysis using folkloristic principles; i.e., the written text has not been revised or edited. The observed story is presented in the form of a dialogue between the two protagonists, and it consists of three thematic parts: preparation for the escape; the journey to the border; and resolving the situations in Sweden. In the introductory part - preparation for the escape - we learn about the search by one of the men for companions with whom to escape from the military unit to Sweden. With regard to looking for companions, they also remember the discussions about what the border that has to be crossed looks like in the men's imagination. When a companion is found, options for escape are sought: for example, the option of going by boat across the Gulf of Bothnia is considered, but neither of the men feel safe at sea, so this plan is discarded and they decide to go by land. Thereafter they talk about their discussions about how to arrange their escape (gathering and hiding the provisions, and about the question of how to get out of the unit so that no one would notice):

Older man: We had taken as much as we could during each meal; we took bread, took it into the forest, and hid it under a tree stump. And so it was on Sunday at around one. We had planned to go that day. [---] took those bread provisions from under the stump there, you know, and just vanished from there, so that nobody would notice.

Younger man: Yes, I also remember it like that, when we came away from the schoolhouse, I was wearing the uniform and went to the toilet. And there I met a Finnish man [---], who looked at me with surprise and said, well, are you going into the village or what. I was wearing the uniform, wasn't I, just walking round there. I told him yes, now, I am going into the village. It was, I believe, yes, around one o'clock or so, when we left.

The second part of the escape story contains the description of the journey. In this part, the ways of describing the geographical space, the experienced events and the duration of the journey (i.e., the timeframe of the event) are highlighted. The space of action can be easily reconstructed: they mention place names and describe landscapes. The important places during the journey are rivers, sentry posts and bridges, which were difficult to cross for one reason or another; forests, 
hay barns, edges of fields - these were important for hiding and having a rest. It appears that when reminiscing about the journey, important landmarks at geographical places are places that are related with experiences, for instance places that were associated with hardships experienced during the journey.

The time frame of events in the story is general - it is from the second half of August to the first half of September 1944. More precise time definitions (e.g. hours) are emphasised in the text when certain decisive moments are described: probably these were also precisely fixed in real life that the story is based on. For example, the moment of fleeing from the unit (it was on Sunday at about one o'clock), or the moment of arriving at the Tornio River:

Older man: That was in the morning, I remember ...

Younger man: Yes, I do remember that. We got there in the morning. The sun was rising. It may have been three or four or something... There was mist on the ground and the sun was rising, and it was light, completely light...

The end of the escape is also defined by a date: it was September 22, when they got a job in Sweden and then went their separate ways. Mostly the reader (or listener of the recording) can perceive the time through the descriptions of weather and the narrators' bodily experiences (e.g., they were extremely cold because 'it was August, and in August it is fairly cold there in the north, there was frost on the grass, tall hay on riverbanks...'). In addition, in these descriptions one can see the comparison of familiar and unknown environments (Schimanski's 'epistemological border'). It is not clear how many days the journey lasted: they count two days (e.g., 'that was on the evening of the second day'), but after that they just mention whether it was evening or morning (e.g., 'it was evening and we had walked quite a distance', 'and see, that was one evening again', or 'we arrived there in the morning. The sun was rising', etc.). According to the descriptions of the days and nights, the journey seems to have lasted not less than four days and nights.

The narrators themselves refer to the escape as a "hike" or a "journey", which in turn consists of single events that they call "adventures" (e.g., "the next adventure that we had was...').

Older man: And the first adventure we had, as I remember, was that we went to $I^{1}$ or whatever it was, went through there to the riverside and there was a Finnish soldier in a boat just about to go across the water, across the Ii River [---]. He took us into the boat, so that we happily crossed that first river and gave two or three cigarettes for that to this soldier. 
Younger man: The first thing I remember... when we went there - there was Olhava station - and bridge [---] and a guard post on the bridge. [Older man: Yes]. And in my opinion, it was the next adventure, after we had come across [the river] at Ii. [Older man: Yes-yes!]

Why use just this word? On the one hand, it is one method of narrating - to talk about real life as an adventure (see Mertelsmann 2011). On the other hand, an 'adventure' sometimes means that they survived, while not to survive could have been 'fate'. For example, when they speak of men they knew who were killed in the war - the situations of their death and not just the fact that they perished - they sum up the topic as follows: 'this was the way his fate was determined'.

There are two types of such adventures or narrative events. One is related to meetings on the bridge, at the sentry posts, on the road. These meetings, mainly with Finnish or German soldiers, were associated with risk. They call hiding away from the roads in the forest to avoid such meetings, or also after the meetings, evaporating (e.g., when they came along a forest path to a glade, into a German camp, they confidently greeted the sentries, but then in retrospect recounted: 'Yeah there, when we had come through there, oh hell, we evaporated into the woods, as soon as we could'). Another type of adventure is associated with nature: e.g., when they avoided roads, 'our forest adventure started: wetlands and wooded bogs'. The most complicated ones, however, were rivers, and there were many in that region:

Younger man: Yes, there were a lot of rivers, as soon as we had crossed one, there was another again not too long afterwards.

Older man: Yes, there were those river bends. Just crossed one, another was ahead! No other way, you have to cross it. Then you walk along the riverbank. We walked past a farm, you know [Younger man: Yes], when we had rafted across there [Younger man: Yes], we came to the river. Started going, by a farm, you know, and there near the farm was a lowland, we went, managed to cross it again [Younger man: Yes], so I don't even remember exactly how we got to the Tornio River.

Generally, they did not have any watercraft. On one occasion, they crossed the river, for example, on a piece of roof that they had previously taken off a house - that was at night, with dogs barking. It was also difficult to cross a river, like the time when they used a boat found on the bank, but there were log rafts moving on the river.

They reconstruct events by reminding one another of them. The conversation partner's words are either confirmed by saying "yes!" now and then, or 
supplemented with details that the other can recall. Recollections are related by placing the escape journey events on the time scale in the specific geographical or perceptual space. In the former case, place names or river names are mentioned, in the latter case the talk is about the landscape and the buildings located there. However, the narrative episodes are most often related to body memory: they recall places where they felt cold ('we were trembling from cold in that hay barn'), fatigue ('we wanted to sleep, but we couldn't sleep there; there were so many evil mosquitoes'), thirst ('I had a water bottle in my hand, it was empty'). They remember places where they had to react bravely when meeting German or Finnish soldiers or even run away quickly, but also episodes, where they scared other people.

Recalling their escape journey, the war mates create a narrative that revolves around the desire to revive the course of real life events. This requires dividing the escape journey into episodes, but also structurally connecting the episodes to each other. The latter is achieved by following the sequence of the events and the geography of the journey. The narration of the story shows how factual information is based on body memory.

The culmination of the story is their arrival at the state border. Then the third part of the story follows: what they experience in Sweden immediately after crossing the border until they are assigned to their jobs. Having crossed the border, i.e., in Sweden, the autobiographical characters in the narrative undergo a change. While in the first and second parts of the story they are active individuals, now they turn into observers-describers of the "other" culture. Also, they do not act on their own, but something is done to or with them: they were sent on a train, taken to Stockholm, given something to eat, imprisoned for a few weeks, etc. Moreover, the story becomes more fragmentary: the men no longer remember what happened and how. They interfere with each other to discuss how it really was. There are no fixed points for telling a fluent story, as the men were no longer the decision-makers in their journey.

Older man: And then we got something to eat, we waited there... how long did we wait there before the police came?

Younger man: Didn't they make a call there?

Older man: ... Haaparanta, yes.

Younger man: I don't know what that was...

Older man: We sat there for about an hour...

Younger man: Definitely, that was definitely about an hour.

Older man: It wasn't far away; it was about three to four kilometres. 
Younger man: And then the police car came.

Older man: Then we were like gentlemen: we were taken to Haaparanta, and then were taken to the sauna; we had something to eat...

Younger man: I don't remember that either.

Older man: We came from the sauna, and were taken to spend the night; see, we were taken to prison...

Younger man: Listen to me, we were not taken to prison, not the first time, it was about one night or two nights that we slept in the police detention rooms.

Older man: Look, I don't remember that.

This is where the analysed story ends, as this was the end of the common period in the biographies of these men. From the aspect of this analysis, however, it is important to note that starting from the description of arriving at the state border and especially in Sweden, the reminiscing process and also the style of narrating changes. In the given case it is particularly significant, because the recording was made in a situation of spontaneous narration, which excluded the possibility of elaborating one's words (making it more artistic or expressive).

\section{TERRITORIAL AND SYMBOLIC BORDERS}

The analysed story shows the multi-dimensional nature of borders: how the narrators themselves perceive the borders, which borders appeared before them in the course of the events, which ones as a result of the choices they made on their own. As this is an episode that concentrates on crossing the state border between Finland and Sweden, we might ask: What is the state border like? It is discussed twice: firstly, the imaginary one, while discussing whether to escape; and secondly, when they actually reach the Finnish-Swedish border. The greatest difference between the imaginary border and the actual one is how the border looked - the recognition of the border. The younger man talks about the border in his imagination at the beginning of the story, when he recalls agreeing to the older companion's suggestion to escape to Sweden. He says:

I do remember the moment when you asked and I thought that I had never been to a border - what would the border look like anyway? - I thought there would be large high-wire fences, and sentry posts after every two or three metres, and I thought how we could ever go through such a place? 
The other man had assured him (he had been to the Estonian border and knew) that 'there are just a few wire fences; you can get through there all right'.

The actual border proved to be quite different. Early in the morning they came to a wide river they thought was the Tornio River, and Sweden was supposed to be on the other side of it. Yet, the men doubted if it was. Therefore, they started looking for signs that would confirm it was the border: the train's whistle heard on the other side of the river seemed different from that heard in Finland; also the landscape (forest stands, farms, plains, hay barns) looked different. Having crossed the river, they observed the landscape again: 'the grasslands were mowed, it was nice and tidy, you know, much different from what it was like in Finland'. What if it was just an island belonging to Finland, they wondered. Nevertheless, as they progressed along the road, they found a sign, the text on which they could not understand: 'That was in Swedish. Then we were sure we were in Sweden.'

The border resulted from the alteration of the status of the autobiographical characters: in one case they were fugitives, in the other, refugees. The emergence of this border in the narrative is supported by several aspects, including, for example, the role of objects in the story. During the escape, objects were aids (for example, in significantly numerous cases the water bottle and its refilling places and moments are pointed out). In the episodes depicting Sweden, objects became a part of descriptions of the culture - here the objects were subjects of observation.

At the level of the event, aspects of the border emerge that enable us to see the distinctness of the border. Besides that, however, the narrative also includes levels that can be viewed as symbolic aspects of the border. For instance, from the interpretive aspect, it is significant that they do not speak about crossing the state border only. Both the events, and the evaluations that the narrators give to the situation, result from the fact that Estonia was under foreign rule (German occupation during 1941-1944, Soviet rule during 1940-1941 and again during 1944-1991). They are Estonians who escaped to Finland to avoid conscription into the occupying German army, and then, both from conscription by the occupying German troops and from the potential Soviet threat, from Finland to Sweden. The border between Soviet Estonia and Sweden during the Cold War, when the story was narrated, is significant for understanding and interpreting the contents of the narrative.

It is namely within this political framework that they question whether their decision - to escape from the Finnish Army to Sweden in September 1944 - was traitorous or not (keeping Estonia and their companions in mind). But then again, were the young men who decided to return to Estonia wrong in their decision? In their discussion they cannot find an exclusively right answer to 
these questions. On the one hand, they do not regret their decision. They do not deny that if others had escaped too, in their words, 'about a thousand good Estonians' would have survived (this number - one thousand - refers to the young volunteers who perished either in later battles or in prison camps). They also point out the other side: if all Estonian volunteers had really decided to escape (i.e., not to return to Estonia), 'there would not be any [Estonian] history'. 'Just think,' they say, '2,000 men went against the great Russia' (approximately 1,800 volunteers came back to Estonia from Finland in August 1944; see Noormets 2011: 44). Therefore, there was the choice of whether to save the individual or Estonia, whether to develop their own life or the history.

To summarise, it can be said that escaping across the state border brought about a moral dilemma. There were two options to choose from: on the one hand, one's own life and self-realisation in a free society; on the other hand, an obligation (maybe an imaginary obligation) to participate in the history of Estonia as a soldier, whose only option is serving in a foreign army, as Estonia did not have its own army any longer. However, in a longer perspective, the escape also brought about borders in the social status of the men. In Sweden they were immigrants who at first did not even know the Swedish language. From the aspect of Estonian society, they also became 'others', those referred to as 'Estonians living abroad'. And furthermore, while their ancestors were Estonians, their descendants lived outside Estonia and did not speak Estonian.

It is obvious that at the level of events the border in this narrative becomes more noticeable when the change takes place within the autobiographical characters. At the same time, to recognise the border, the characters need hints and signs confirming that they have crossed the state border. At the level of evaluations and discussions, the border associated with the role changes (an Estonian in Sweden) fades away, while political borders in the Cold War context remain unambiguously clear.

\section{CONCLUSION}

The story analysed here reflects a view of the Finnish-Swedish border: how it was seen and perceived by two refugees at the end of World War II. The story is framed by the description of the border. Narrating the story starts with describing the imaginary border and the intention to cross the border, and ends with a detailed description of the crossing. Yet, the same story also contains other levels of border crossing. One way to recognise that they were in Sweden was seeing that the culture "here" was different, but also that the meadows and farm homes were different from those in Finland, which was at war. This, 
in turn, was connected with the fact that the Finnish-Swedish border marked the border of warfare. For these soldiers, it also represented the border between their fugitive status and freedom. In addition, the men discuss how to evaluate the border crossing from the standpoint of their own and their companions' life course. They evaluate their own fate in the biographical context: escaping gave them a possibility of self-realisation in a freer society, the alternatives to which they do not really know. What they say about the fate of their war mates falls into the political (and not biographical) context.

The recounted war period in their life lasted for slightly more than two years, and the escape journey within it just over a month. At the same time, this border crossing is one of the key points in the course of their lives. Although the general plan of the narrative is dedicated to the details of the escape journey, the narrative also reveals the reason why they want to recall and interpret this episode in their lives. They discuss the moral aspects of their decision, contemplating where their action is placed in the context of the other Finnish Boys (Estonians fighting in the Finnish Army) or in the context of the fate of Estonians in general; how to interpret their decision and their following life in the context of Estonian history.

Because the men were now reunited for the first time after the recalled events, this escape story had not been told in the same form before. As a spontaneous narrative, this story offers an opportunity to analyse the mutual relationship of the events and the protagonists and its role in the remembering process. The differences in the relations between the autobiographical "me" and the events come to the fore in the comparison of the situation before and after the border crossing. When describing their journey, although they were unable to determine and control the scenario of the events experienced during the journey, they describe every event, being the protagonists in it. Remembering the past was fluently expressed: they visualised the time and the place of activity (whether it was morning or evening, whether a meeting took place on the road or a bridge or in the forest). Based on this, the described situation was placed in the complete picture of the escape journey. However, when they described themselves as refugees in Sweden, they presented themselves as men in a passive state of expectancy (waiting for what would be done with/to them) and observers of the surrounding environment. They were no longer active in shaping the events, and the recounting of this period became fragmentary. They did not remember the key points that would have helped them create fluent episodes, in the context of the narrative. The positioning of the first-person character with regard to the events and the frames of interpretation (e.g. the moral aspects of their decision, comparison with war mates and compatriots) refers to the continuing process of shaping and conceptualising the experience. 
This narrative offers a chance to analyse the topic of the border, joining the border concept that has arisen from political geography with the poesy of placing the border into a narrative. On the one hand, it was apparent how the political-geographical and historical frameworks affected people's choices in moving from one place to another, and how this in turn shaped their subsequent course of life. Changes that had taken place both in one's biography and in society caused a need to look back at one's story once again - either to confirm or to review one's standpoints. At that level of the story, the qualities of (crossing) the border as a process were revealed. On the other hand, the poetic aspect of describing the border was emphasised. This included the features of depicting the time and space context of the events, for example, the feelings and bodily experiences of the main characters, the activity or inactivity of the characters in the course of the events, the personal and the unfamiliar cultural spaces. Although this narrative was not created for artistic purposes, it appeared that when describing the different aspects of the border (imaginative border, real state border, symbolic borders), inevitably also the style of presenting the story changed (e.g., the position of the main character, the way of observing and describing the environment).

\section{ACKNOWLEDGEMENTS}

The article was supported by the Academy of Finland, project Traumatized Borders: Reviving Subversive Narratives of B/Order, and Other (SA 297533), and the Estonian Ministry of Education and Research, project Tradition, Creativity and Society: Minorities and Alternative Discourses (IUT 2-43).

\section{NOTES}

1 Ii is a municipality of Finland. It is situated at the Bothnian Bay, at the mouth of the River Iijoki, and it is part of the Northern Ostrobothnia region.

\section{ARCHIVAL SOURCES}

EKLA 350 - manuscript collection of the Estonian life histories (1989-), Estonian Cultural History Archives at the Estonian Literary Museum, Tartu.

MK: Stockholm 2008, E. T. - materials collected by the author in Sweden in 2008, preserved at the Department of Estonian and Comparative Folklore, University of Tartu. 


\section{REFERENCES}

Allison, Randal S. 1997. Personal Experience Narrative. In: Thomas A. Green (ed.) Folklore: An Encyclopedia of Beliefs, Customs, Tales, Music, and Art. Vol. II. Santa-Barbara, California \& Denver, Colorado \& Oxford, England: ABC-CLIO, pp. 635-637. Available at http://www.rhymesworld.com/sitebuildercontent/ sitebuilderfiles/2285284.pdf, last accessed on 5 September 2018.

Apo, Satu 1995. Naisen väki: Tutkimuksia suomalaisten kansanomaisesta kulttuurista ja ajattelusta. [Female Väki-Force: Studies in Finnish Folk Thought and Culture.] Helsinki: Hanki ja jää.

Bluck, Susan \& Alea, Nicole 2008. Remembering Being Me: The Self Continuity Function of Autobiographical Memory in Younger and Older Adults. In: Fabio Sani (ed.) Self Continuity: Individual and Collective Perspectives. New York: Psychology Press, pp. 55-70.

Custred, Glynn 2011. The Linguistic Consequences of Boundaries, Borderlands, and Frontiers. Journal of Borderlands Studies, Vol. 26, No. 3, pp. 265-278. https:// doi.org/10.1080/08865655.2011.675716.

Jaago, Tiiu 2011. The Lucky Star and Discernment: The Positioning of the Self and War in the Life Story of Lembitu Varblane. In: Ene Kõresaar (ed.) Soldiers of Memory: World War II and Its Aftermath in Estonian Post-Soviet Life Stories. Amsterdam \& New York: Rodopi, pp. 317-342.

Kirss, Tiina 2006. Põgenemisteekonnad ja põgenemislood. [Escape Journeys and Escape Stories.] In: Tiina Kirss (ed.) Rändlindude pesad: Eestlaste elulood võõrsil. [The Nests of Migratory Birds: Life Stories of Estonians Abroad.] Tartu: Eesti Kirjandusmuuseum \& Toronto Ülikooli Eesti õppetool, pp. 611-646.

Lawler, Steph 2008. Stories and the Social World. In: Michael Pickering (ed.) Research Methods for Cultural Studies. Edinburgh: Edinburgh University Press, pp. 3249. Available at https://lcst3789.files.wordpress.com/2012/01/pickering_ed_ research_methods_in_cultural_studies.pdf, last accessed on 5 September 2018.

Leemets, Margus (ed.) 1997. Vabaduse eest. Soomepoiste lühielulood. [For Freedom: Brief Life Histories of the Estonian Volunteers in the Finnish Infantry Regiment.] Tallinn: Soome Sõjaveteranide Eesti Ühendus. Available at https://www.digar. ee/arhiiv/et/raamatud/81057, last accessed on 5 September 2018.

Mertelsmann, Olaf 2011. Boris Raag - Hope of Staying Alive: Survival Strategies of a Soviet Soldier. In: Ene Kõresaar (ed.) Soldiers of Memory: World War II and Its Aftermath in Estonian Post-Soviet Life Stories. Amsterdam \& New York: Rodopi, pp. 263-277.

Newman, David 2003. On Borders and Power: A Theoretical Framework. Journal of Borderlands Studies, Vol. 18, No. 1, pp. 13-25. https://doi.org/10.1080/0886565 5.2003.9695598.

Noormets, Tiit 2011. Estonians in World War II: A Chronology. In: Ene Kõresaar (ed.) Soldiers of Memory: World War II and Its Aftermath in Estonian Post-Soviet Life Stories. Amsterdam \& New York: Rodopi, pp. 35-46.

Paasi, Anssi 1996. Territories, Boundaries and Consciousness: The Changing Geographies of the Finnish-Russian Border. Chichester \& New York \& Brisbane \& Toronto \& Singapore: John Wiley \& Sons. 
Palmenfelt, Ulf 2006. The Dark Shadow of the Un-Mentioned Event: Collapsing Taleworlds and Narrative Reparation. In: Annikki Kaivola-Bregenhøj \& Barbo Klein \& Ulf Palmenfelt (eds.) Narrating, Doing, Experiencing: Nordic Folkloristic Perspectives. Studia Fennica: Folkloristica 16. Helsinki: Finnish Literature Society, pp. 101-116.

Pickering, Michael 2008. Experience and the Social World. In: Michael Pickering (ed.) Research Methods for Cultural Studies. Edinburgh: Edinburgh University Press, pp. 17-31. Available at https://lcst3789.files.wordpress.com/2012/01/pickering ed_research_methods_in_cultural_studies.pdf, last accessed on 5 September 2018.

Schimanski, Johan 2006. Crossing and Reading: Notes towards a Theory and a Method. Nordlit, Vol. 19, pp. 41-63. http://dx.doi.org/10.7557/13.1835.

Schimanski, Johan \& Wolf, Stephen 2010. Cultural Production and Negotiation of Borders: Introduction to the Dossier. Journal of Borderlands Studies, Vol. 25, No. 1, pp. 38-49. https://doi.org/10.1080/08865655.2010.9695749.

Uustalu, Evald \& Moora, Rein 1973. Soomepoisid: ülevaade Eesti vabatahtlike liikumisest ning sõjateest Soomes ja kodumaal Teise maailmasõja päevil. [Finnish Boys: An Overview of the Movement and War Experiences of Estonian Volunteers in Finland and Estonia during the Second World War.] Toronto: Soomepoiste Klubi Torontos.

Varblane, Lembitu 2011. Born Under a Lucky Star. In: Ene Kõresaar (ed.) Soldiers of Memory: World War II and Its Aftermath in Estonian Post-Soviet Life Stories. Amsterdam \& New York: Rodopi, pp. 163-185. 